Géopolitique de la connaissance et transferts culturels

\title{
Art and Chinese Modernity in Connection with Lyon, 1920s-1940s
}

WANG Yiyan

\section{(2) OpenEdition}

\section{Journals}

\section{Electronic version}

URL: http://journals.openedition.org/transtexts/512

DOI: $10.4000 /$ transtexts.512

ISSN: 2105-2549

Publisher

Gregory B. Lee

Electronic reference

WANG Yiyan, «Art and Chinese Modernity in Connection with Lyon, 1920s-1940s », Transtext(e)s Transcultures 跨文本跨文化 [Online], 9 | 2014, Online since 20 September 2015, connection on 30 April 2019. URL : http://journals.openedition.org/transtexts/512 ; DOI : 10.4000/transtexts.512

This text was automatically generated on 30 April 2019

(C) Tous droits réservés 


\title{
Art and Chinese Modernity in Connection with Lyon, 1920s-1940s
}

\author{
WANG Yiyan
}

\section{Introduction}

1 Modernisation of art was an integral part of China's national modernisation project, which China undertook when faced with serious threat of European and Japanese imperialism from the latter half of the $19^{\text {th }}$ century. ${ }^{1}$ After the founding of the Republic of China in 1912, measures to expand "Western learning" sped up with many students going overseas to study and Western ideas being translated into Chinese. European concepts and practice of art were also rapidly introduced and learnt. By the third decade of the $20^{\text {th }}$ century, the concept and practice of art in China had been completely transformed. In 1929 China's first national art exhibition, organised by the Ministry of Education, was held with overwhelming success and included many genres originating in European traditions, such as oil painting, sculpture, photography and architectural models. ${ }^{2}$

2 The national art exhibition was conceived at the very founding of the Republic of China by its first minister of education, Cai Yuanpei 蔡元培 (1868-1940). He considered aesthetic education a priority in China's drive towards modernisation and a viable and preferable substitute for religion. ${ }^{3}$ Among Chinese students studying overseas in the first decades of the $20^{\text {th }}$ century, several hundred studied art. France was favoured as a destination for Chinese students, partly because France had a labour shortage and welcomed Chinese students for that reason. China was keen to send as many students as possible to study overseas. Initially many students went to Paris and they worked in various factories to support themselves while studying. Lyon was subsequently chosen as the location of a joint venture between China and France for the education of Chinese students. The mayor of Lyon was particularly friendly to the Chinese government of the day and to Chinese students. The Institut franco-chinois de Lyon (hereafter IFCL) was established in 1920 to accept, prepare and accommodate Chinese students before their formal enrolment in French universities. 
3 A number of the Chinese art students who later established their reputation in Paris first went to study in Lyon and were graduates of the École national des beaux-arts de Lyon (National Art School of Lyon). Chinese art historians have been highlighting the impact and influence of the École des beaux-arts de Paris on modern Chinese art history. ${ }^{4}$ The significance of the National Art School of Lyon in the process of China's art modernisation, however, has been overlooked. This paper will explore the direct connection between Lyon and China in the first decades of the $20^{\text {th }}$ century through selected cases of Chinese art students. It will demonstrate how the trajectories of those individuals exemplified China's drive towards the modernisation of art, both in terms of institutional measures and individual efforts.

\section{National Art School of Lyon (L'École nationale des beaux-arts de Lyon)}

4 L'École nationale des beaux-arts de Lyon (National Art School of Lyon, henceforth ENBAL) was established in 1757 and was one of the best art schools in Europe by the 20th century. ${ }^{5}$ Arthur Efland, a scholar specialising in the history of art education, shows that the French art schools were highly admired by others, such as the English, and that ENBAL's courses were most comprehensive and of excellent quality. ${ }^{6}$ The Chinese evaluation also confirms this observation. According to a special report by Xiong Qingyun published in 1923 in the Chinese Educational Review (Jiaoyu zazhi), the official Chinese government monthly publication by the Ministry of Education at the time, ENBAL was the second best in France and Europe, with only l'Ecole des Beaux Arts de Paris having a higher reputation. At the time there were in total more than 700 art schools in France, some focusing on fine art, some on industrial art, some on architectural art including sculpture. L'Ecole des Beaux Arts de Paris offered three majors: 1. Painting; 2. Sculpture; 3. Architecture. Among the three, fine art and sculpture are the most celebrated. ENBAL offered four majors: 1. Painting; 2. Sculpture; 3. Architecture; 4. Decorative Art. The Decorative Art major was divided into two sub-majors: a. industrial design, including textile design, metal, timber and other sculptural decorative designs; b. applied art and design, such as advertising. Students majoring in Decorative Art were required to complete both sub-majors. Of the four majors at ENBAL, the best known were Architecture and Decorative Art, especially the textile design component (Lyon having been the primary location for France's textile industry). ${ }^{7}$

5 Both schools offered free tuition, except that in Lyon, students majoring in decorative art had to pay a fee. To be eligible to take part in the entrance examination, candidates must have matriculated through the French high school system. The procedures were largely the same for both domestic and foreign students, namely, each year all candidates competed in the examinations taking place in April and May. For foreign students, an additional requirement was that they had to obtain permission from the French Ministry of Education, accompanied by a letter of introduction from their respective embassies. The subjects of examination were numerous and complicated, although candidates could ask for information beforehand. Each year there were large numbers of candidates and the numbers admitted by the two schools (Paris and Lyon) were extremely limited - about 20 formal students in each major, about 100 students in preparation, and 20 to 30 auditors. In short, it was very difficult to gain entry to ENBAL and for Chinese students, gaining admission was certainly a high achievement already. 


\section{L'Institut Franco-Chinois de Lyon (中法大學)}

6 L'Institut franco-chinois de Lyon (IFCL) was an institution jointly set up by the Chinese and French governments in 1921 and it functioned, more or less, until the late 1940s. On the Chinese side, the intention was to have a university in France to provide more opportunities for Chinese students to study in Europe. Students were to be selected according to academic merit. The French, on the other hand, saw it as a good opportunity to establish connections with China and they were also happy to have Chinese students as a complementary workforce, since there was an extreme labour shortage after World War I. Lyon was chosen for a number of reasons but primarily for its openness in accepting other cultures and also for the familiarity with Lyon enjoyed by the Chinese founders of IFCL. Cai Yuanpei, again, was personally involved with the setting up of the institute and a number of the students who studied art were directly supported by him. ${ }^{8}$

7 The name of IFCL in French differs from that in Chinese. In Chinese, IFCL had university status, as shown in the name Zhongfa daxue (Chinese-French University). Indeed, students had to go through the same admission procedures as for the universities in China of the time and entrance was competitive. IFCL's primary function, however, as suggested by Xiong Qingyun, was to assist its students to settle into the new environment. But it did far more than simply preparing students for entry to universities. It provided students with accommodation, food and studying facilities, such as the library. It offered scholarships and other financial assistance to students on the basis of academic merit. It also functioned as legal guardian on behalf of the students.

IFCL had a good filing system and kept files on most of its students, although some files have far more information than others. IFCL also kept all the books and journals that its library used to hold, including many sent by students who had returned to China and whose writings appeared in the materials. All the IFCL materials are now professionally catalogued and in the safekeeping of the Lyon Municipal Library at La Part Dieu. Files on the following 17 art students are kept:

Women students:

蘇梅 Su Mei (also known as 蘇雪林)

潘玉良 Pan Yuliang

方䌁 Fang Yun (Lancy Fang)

王靜遠 Wang Jingyuan

范新群 Fan Xinqun (Silvia Fan)

李慰慈Li Weici

陳芝秀 Chen Zhixiu (Mme Dsang)

劉淑芳 Liu Shufang (Mme Chen)

18 Men students:

19 邱代明 Qiu Daiming

20 黃葉 Huang Ye

21 棌福熙 Sun Fuxi

22 常書鴻 Chang shuhong 

registration at entry (inscription) and the prizes and scholarship given to students from each class by the School (année scolaire et récompenses). The registration record was entirely hand-written during the decades corresponding to the presence of the Chinese students, and can be difficult to decipher at times. Student registration keeps information on: date of registration; family name (for married women also their maiden family name) and given name; gender of the students; date and place of birth; names of their parents (not always recorded); current address in Lyon; and other information and comments, such as whether they were also students at IFCL. The last column was called "observations" and "prizes" (observations - récompenses), which was left blank most of the time, but on occasion there were notes about prizes won by the students, when the student left the School, and if the student was from IFCL. The records were by no means complete or accurate and discrepancies do exist between records kept by IFCL and ENBAL.

However, records of prizes were kept meticulously by ENBAL. Each school year all prizes and scholarships given to students were recorded according to classes. The names of the professors who taught the classes were listed under each class. There was one booklet of prizes for each year, and in time they would be bound into cumulative volumes of records for four or more years. See below a page from the Prize records of ENBAL. 


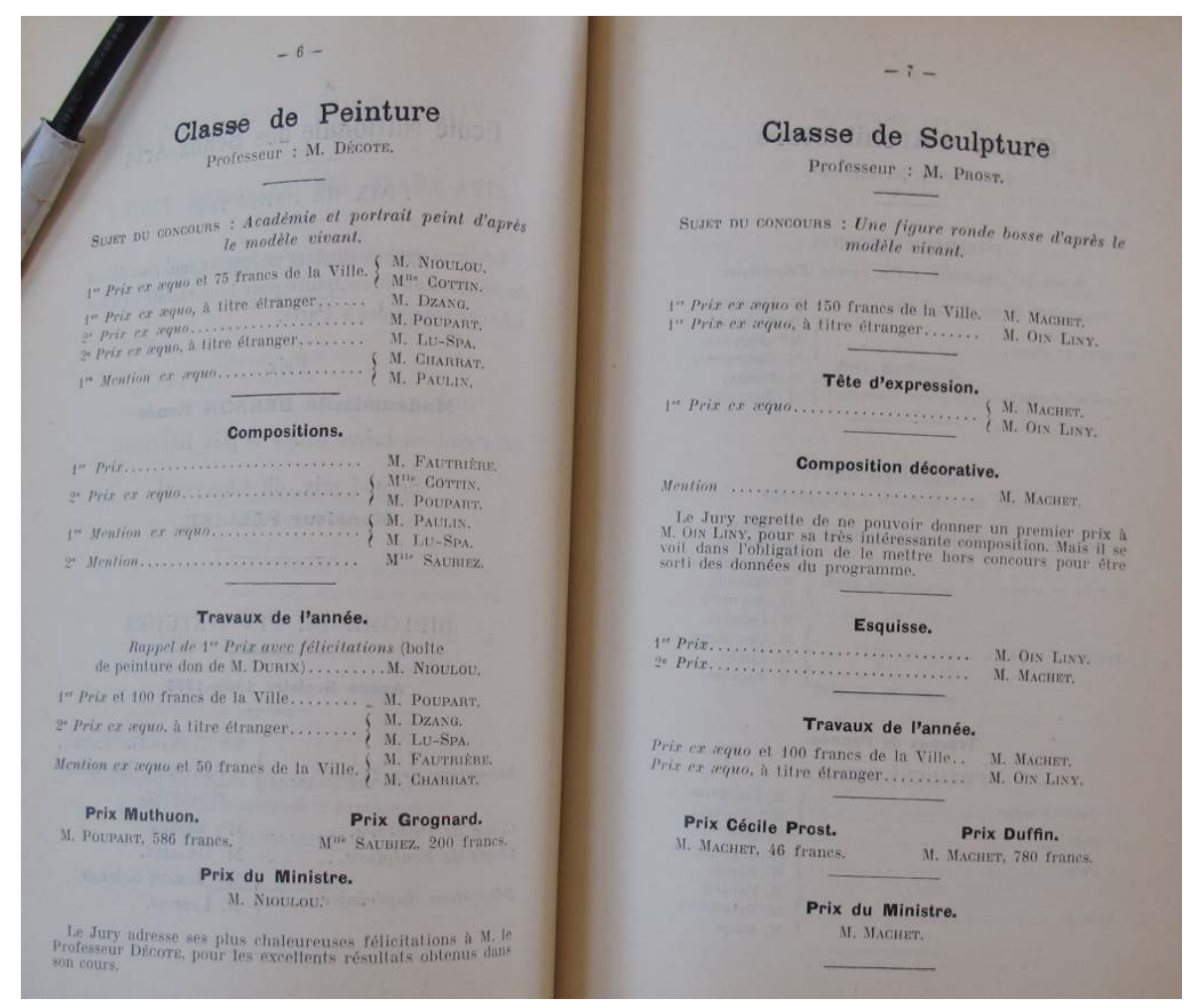

31 My research finds approximately 58 students from China registered at ENBAL. The number is not accurate because I rely on the registration record, and especially on how the students spelt their names. If I believe someone was from China I will then consult the specific page to verify his or her birthplace. I may have missed some who had Europeanised the spelling of their names too much, but it is not possible for me to go through all the student records one by one, given the limited time at hand. It might also have happened that some students did not register with ENBAL but with other institutions, such as l'Ecole municipale de dessin (the School of Design), which was run by the municipality of Lyon and did not keep student records at the time.

Among the 58 art students, 42 were male and 16 were female. A few students were married with children but most of them were single. They came from many parts of China, although the majority were from the Jiangnan region, especially from cities such as Shanghai, Hangzhou, Suzhou and other parts of Jiangsu and Zhejiang. The second most common place of origin is Guangzhou, followed by Beijing. There were also students from Hunan, Sichuan, Anhui and Fujian.

Chinese students started winning prizes at the school almost as soon as they arrived. From 1921 to 1942, the last year in which the list had a Chinese winner, each year a number of prizes would go to students from China. From ENBAL's prize records, I am able to identify 36 prize winners with Chinese names. Among them, 16 were women and 20 were men. Many of them also won multiple prizes each year for their study period at ENBAL. A few showed extraordinary talent and had outstanding achievements. Wang Jingyuan 王靜遠, Chang Shuhong 常書鴻, Lü Sibai 呂斯百, Chen Shiwen 陳士文, Fang Yun 方䔋, Liu Shufang 劉淑芳, Chen Zhixiu 陳芝秀 (wife of Chang Shuhong at the time), Wang Linyi 王臨乙, Hua Tianyou 滑田友all stood out as excellent students. Wang Jingyuan and Chang Shuhong were the two highest achievers at ENBAL, winning the School's top prizes. Wang Jingyuan was the top student in the Sculpture major for the 
1926-1927 school year and was awarded a prize and a travel bursary. Chang Shuhong majored in painting and topped the entire School in 1932. The prize included a scholarship for further study in Paris. These were extraordinary accomplishments, considering how competitive and difficult it was to gain entry to the School to begin with. ${ }^{9}$ She was a scholarship holder with IFCL and was a "first" in a number of ways. In 1921 she was the first woman, the first Chinese and foreign student to be awarded a prize for the class of "Facial Expressions" (Tête d'expression), although it was only an "encouragement" (Félicitations du Jury). That, however, was just the beginning. She successfully completed all the course requirements to qualify for her degree and graduated with top honours in 1926. In the prize books of ENBAL, she is listed as having taken the following classes and winning various orders of prizes:

\begin{tabular}{|c|c|c|}
\hline School Year & Class & Prize \\
\hline 1921-1922 & Facial Expressions & Félicitations du Jury \\
\hline \multirow[t]{3}{*}{$1922-1923$} & Study of the figure & Mention ex-aequo \\
\hline & Facial Expressions & $2^{\text {nd }}$ Bronze Medal \\
\hline & Sculpture & $1^{\text {st }}$ Mention \\
\hline \multirow[t]{5}{*}{$1923-1924$} & Sculpture & \\
\hline & Facial Expressions & $2^{\text {nd }}$ Prize: Bronze Medal \\
\hline & Sketch of the Year & $2^{\text {nd }}$ Prize: Bronze Medal \\
\hline & Work of the year & $1^{\text {st }}$ Prize: Silver Medal \\
\hline & Decorative Art (all items considered) & $1^{\text {st }}$ Mention \\
\hline \multirow[t]{3}{*}{$1924-1925$} & Scholarship of the year & Mention with the title of foreign student ${ }^{10}$ \\
\hline & Life drawing competition & $1^{\text {st }}$ Prize \\
\hline & Head Expression & $1^{\text {st }}$ Prize \\
\hline $1925-1926$ & Sculpture & $1^{\text {st }}$ Prize \\
\hline
\end{tabular}




\begin{tabular}{|l|l|l|}
\hline & Life drawing competition & $1^{\text {st }}$ Prize \\
\hline $1926-1927$ & Scholarship of the year & \\
\hline & Sculpture & Sculpture Prize of the Year \\
\hline
\end{tabular}

In the six years that Wang Jingyuan studied at ENBAL, she won numerous prizes each year and finally became the top student in 1927 - she was awarded the top prize for sculpture for the school year of 1926-7 and a travel bursary - the first time in the history of ENBAL that such a prize had gone to a woman and a foreigner.

Wang Jingyuan's achievements were also acknowledged by the authorities at IFCL. Despite the financial constraints the Institute was experiencing, in 1927 before returning to China she asked the IFCL to fund her study trip to Italy and the board of IFCL agreed to it. When IFCL was booking her boat ticket to return to China, she asked that her sculpture works be sent back with her to Beijing and that the works be insured at the value of 20,000 francs. The final document relating to her return trip to China shows that all her works were insured for the ocean journey to Shanghai against maritime risk only at an extra cost of 300-900 francs. ${ }^{11}$

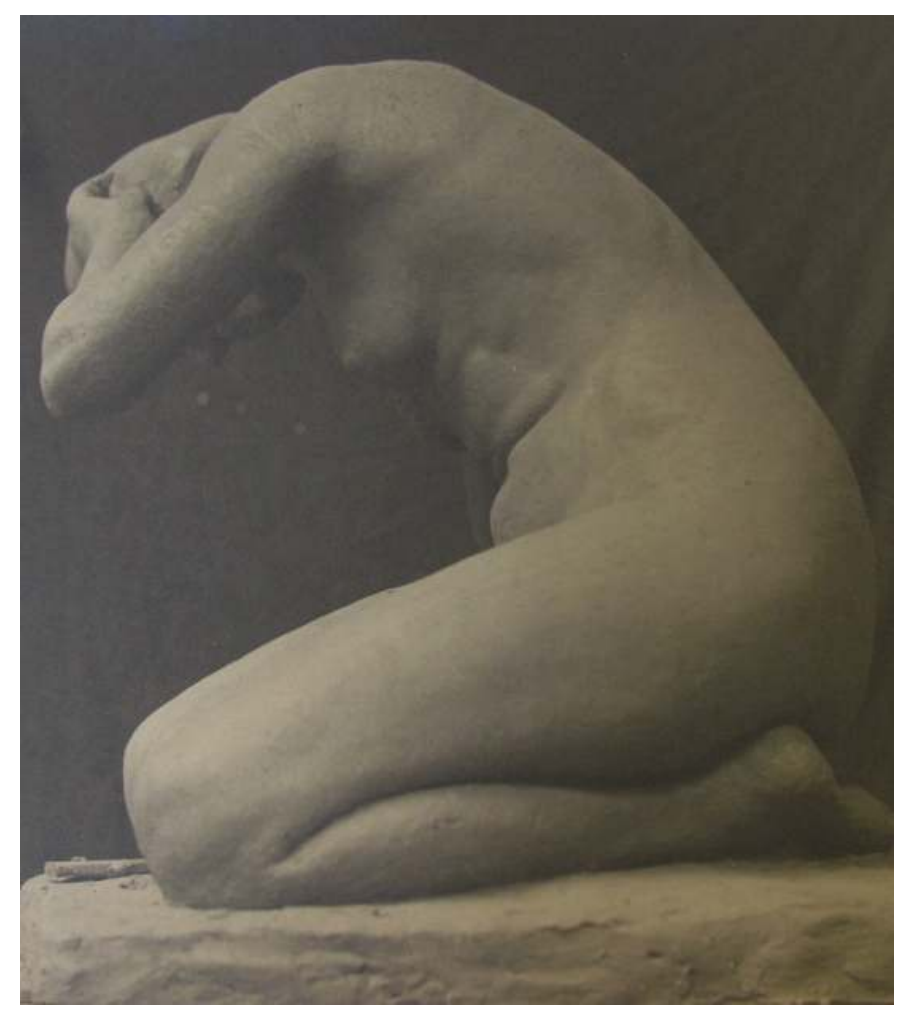

(one of the photos of Wang Jingyuan's sculptures in her file)

There are photos of eight of Wang Jingyuan's sculptural works in her files kept by IFCL. Three of the works are "facial expressions", of a man and two women. The rest are nudes of men and woman in various postures. All of them are untitled and all the models are European. Clearly, these are the works that Wang created during her study at ENBAL and that earned her the prizes. All are works of academic realism and consistent in their style of fine, clear features. 


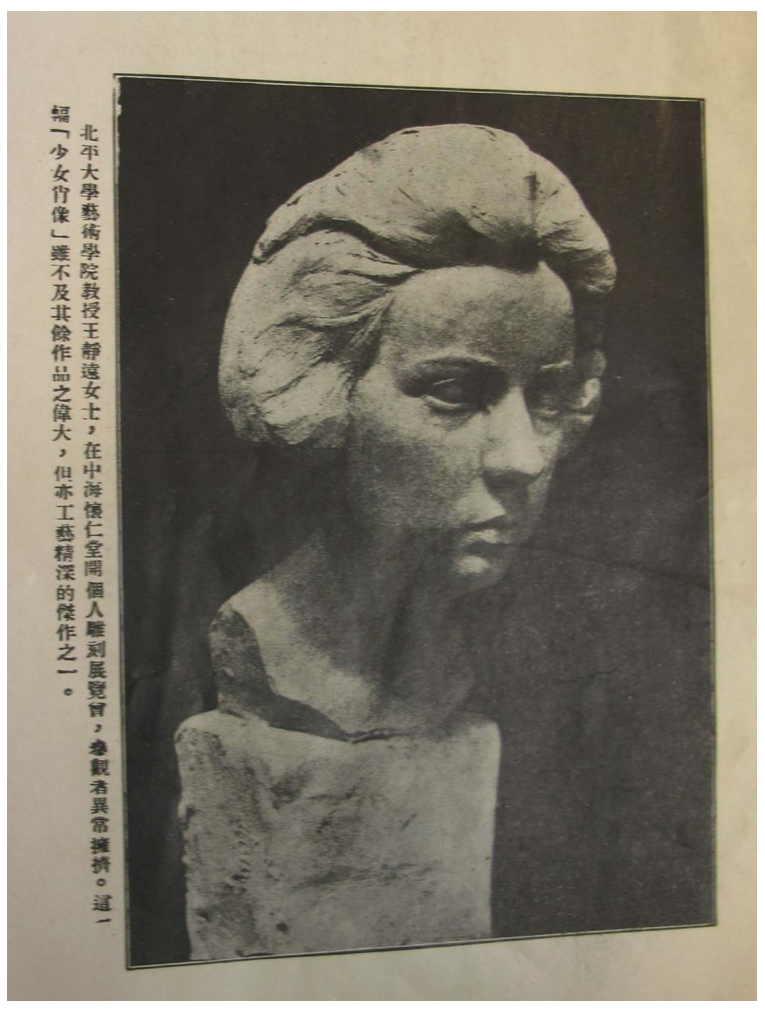

Sculpture at the Department of Fine Arts at Peking University. South China Literature and Art 《華南文藝》reported an exhibition Wang Jingyuan held in September 1932 with the photo of a sculpture of a woman's head by Wang. The caption says: "Mme Wang Jingyuan, Professor of Sculpture of the Department of Fine Art at Peking University, held a solo sculpture exhibition at the Forbidden City. It attracted large crowds. This 'Portrait of a Young Lady' shows the delicate skills of the artist, although it is by far not nearly as grandiose as her other works." The report, interestingly, chose to use the head sculpture to demonstrate the artistic talent of this woman. Why not another, grander piece? One explanation could be that most of Wang Jingyuan's sculpture works are nudes of men and women. Given the cultural atmosphere of China in the 1930s, it was still safer for a magazine not to publish a woman sculptor's works of nudes, although at the same time it is understandable that in Beijing the show could attract a large audience in a very respectable venue.

43 Information about Wang Jingyuan's life and work after the founding of the People's Republic of China (PRC) is scarce. Chinese websites offer various kinds of information her but some details are clearly wrong, such as her age. It is possible, however, to infer that she taught sculpture at various institutions and was a consultant for the Sculpture Production Workshop set up by the Ministry of Culture of PRC in the 1950s. ${ }^{12}$

Pan Yuliang (Pein Yu-lin) and Li Weici (Ly Wei-tse) were also excellent students at ENBAL. Pan Yuliang enrolled at ENBAL on $3^{\text {rd }}$ November 1921 and left in May 1924 while she was also a student at IFCL with a scholarship provided by Anhui Provincial Government. In her three years at ENBAL, she gained a $4^{\text {th }}$ mention and a prize for her achievement in the school year of 1923-1924. In Paris, however, she became relatively well-known and exhibited regularly with independent galleries. In recent years, she has increasingly

Transtext(e)s Transcultures 跨文本跨文化, 9 | 2014 
attracted scholarly attention and is now widely regarded as a leading Chinese painter of her time. John Clark, in Modernities of Chinese Art, has high regard for Pan Yuliang's emphasis on representing the individual, especially the Chinese woman. Clark sees her as a better artist than $\mathrm{Xu}$ Beihong, one of the most prominent and influential artists in China from the 1920s to 1950s. The Anhui Provincial Museum has now developed a full collection of Pan Yuliang's works. In an exhibition organised by Musée Cernuschi in Paris in 2011, Pan Yuliang's works were exhibited among the most prominent Chinese artists of the day. ${ }^{13}$

Li Weici's enrolment date at ENBAL was 21 January 1930. She was also a student at IFCL, which kept some of the correspondence between ENBAL and IFCL about her. Apparently, she was rather sickly and ill health kept her from attending classes. She was reprimanded in writing by her professor about her frequent absence from class and had to submit a doctor's certificate to explain. Li Weici, however, was gifted and managed to win recognition and some prizes in the end. Although unfortunately there are no records of her works available to date, there is evidence that she went back to Guangzhou and wrote articles for art journals introducing contemporary European artistic trends. ${ }^{14}$ She was active in Guangzhou and a member of the Young Artists Association (青年藝術社) based in Guangzhou.

Chen Zhixiu 陳芝秀 was another Chinese woman sculpture student at ENBAL, although she arrived after Wang Jingyuan had departed. In the student records, she registered as Mme Chang, as the wife of Chang Shuhong. They married in around 1925 before Chang Shuhong departed for France. In the IFCL files, she registered in her own name but much of the information about her is kept with the files of Chang Shuhong. Chen Zhixiu, however, was very much an independent soul. To begin with, she made the sea voyage of weeks to and from France on her own, and on the return journey she had the care of their young daughter. She was admitted to ENBAL as a preparatory student upon her arrival in 1929 but in the same year she won prizes and became a formal student. In a letter from the administrator of ENBAL to the president of IFCL, she was listed as number two among the four IFCL students given prizes on that occasion. Number one was Chang Shuhong and the other two were Li Weici and Lü Sibai.

In March 1931, Chen Zhixiu gave birth to Shana, her daughter with Chang Shuhong, and continued her studies soon afterwards. In her file, there is a postcard with the images of two sculptures by her. They are busts of her daughter Shana and fellow student, Lü Sibai; in other words, she used as her models people with whom she was familiar. Her own image has been perpetuated in the paintings of her husband, Chang Shuhong. One of the paintings with her as model and subject, "Portrait de Madame D.", won high praise for enabling a "fusion between the West and the East". ${ }^{15}$ Francesca Dal Lago mistakenly writes that Chen Zhixiu started studying sculpture only after her family settled in Paris. ${ }^{16}$

Again, it is not clear what she did professionally after she returned to China. Information on her is scarce, except that her divorce from Chang Shuhong was widely publicised in a documentary film on Chang Shuhong in recent years. Apparently, she reluctantly joined Chang Shuhong when he went to work at the Dunhuang Caves and eventually decided to leave the place and her husband.

Fang Yun (方藴 Lancy Fang) studied at ENBAL from 1922 to 1927. She was one of the earliest of Chinese students to major in decorative art. Based on information about the prizes given to her, the courses she studied include: Decoration, Composition Applied on Fabric, and Decoration on Ceramics. The Decorative Art major was very demanding at 
ENBAL and students were required to study courses specific to their own major as well as other general courses of art education. Fang Yun is another outstanding achiever - she started winning prizes in the same year she enrolled and was to win numerous prizes every year throughout her study there. Once again, there is no information available about her after she returned to China.

Two other women students, Fan Xinqun (范新群) and Liu Shufang (劉淑芳), had similar trajectories. They were simply brilliant students with numerous prizes at ENBAL. In their student days gender issues did not seem to matter - they were able to enter the school and win recognition on merit with achievements no fewer than their male counterparts. However, after they had graduated and returned to China, they disappeared from public view.

51 Considering how few women students were in the entire student population at ENBAL in the 1920s, these Chinese women were extremely courageous in venturing into another language, culture and academic tradition thousands of miles from home. They were, in a sense, literally the products of the May Fourth Cultural Movement that started in the late 1910s in China, which laid the ideological and infrastructural foundation for young women to pursue a career in art. Given the social and historical context, the achievements of the Chinese women students at ENBAL were indeed extraordinary.

\section{The High Achievers among Chinese Male Students at ENBAL}

52 Judging from the list of prizes and scholarships, the numbers of Chinese male and female prize winners were similar. They seemed to have equal footing at ENBAL, although their years of study did not coincide. Most of the male high achievers arrived in 1928 or later, after the first cohort of female students had graduated. Despite their similar starting points, their career trajectories after their student days would turn out to be very different. Many of the male students would return to China to hold key positions at educational institutions, and they had more opportunities to utilise their artistic talent and skills. The most outstanding male students include Chang Shuhong, Lü Sibai, Wang Linyi and Chen Shiwen. Hua Tianyou was the recipient of a scholarship from IFCL but he studied primarily in Paris.

Before coming to ENBAL, Chang Shuhong had already graduated from Nanjing Institute of Technology with a diploma in textile design. Although he and Chen Zhixiu were married, he went to France on his own first. He lived and worked in Paris for a short while before going to Lyon to enrol in both IFCL and ENBAL. He was initially admitted to ENBAL as a preparatory student in 1929 to study painting and decorative art. He started winning prizes in the same year and for the four years he was at ENBAL, he was recipient of multiple prizes. It was his winning of the top prize, Le Prix de Paris, in 1932 that enabled him to continue his studies in Paris.

54 Chang Shuhong is the subject of a monograph published in 2011. As its subtitle "from Paris to Dunhuang" indicates, the book concentrates on Chang Shuhong's days in Paris and the rest of his working life in Dunhuang, with only a brief mention of his days in Lyon. He is also one of the artists featured in Lefebvre's book on Chinese artists in Paris and again, his training at ENBAL is not discussed, as if his four years of study there had no implications for his subsequent creativity. ${ }^{17}$ Paris, of course, was significant for Chang 
Shuhong in at least two aspects. First, it gave him recognition in Paris, where his works topped Parisian art salons and his exhibitions were attended by dignitaries and diplomats. Second, he got to know the significance to art history of the Dunhuang Buddhist caves in China's northwest, where he would spend most of his working years from the 1950s to the 1980s in documenting and preserving the precious frescos there.

In France, Chang Shuhong painted in the style of academic realism and his subjects were the usual categories for academic paintings: portraits, nudes, landscapes and still lifes. His technique was superb but his breakthrough really happened after he took Chinese women as his subjects. His "Song of Exile" (Le Chant de L'Exil, 1931) attracted attention immediately from critics. His painting, "Two Sisters at a Salon" (Deux soeurs au salon, 1936) won the gold medal for the year at Salon du Printemps in Paris. The two sisters are Chinese women dressed in cheongsam reading a book in the typically French-style salon setting. ${ }^{18}$

Lü Sibai and his close friend Wang Linyi both enrolled at ENBAL in 1929 and studied there until 1934. Both were mentored by $\mathrm{Xu}$ Beihong and it was Xu who encouraged them to study at ENBAL. Lü Sibai was a student of painting whereas Wang Linyi studied sculpture. Both men won numerous prizes in their chosen genres while at ENBAL. Their artworks can be found in the Chinese magazines in the 1930s and they were also prolific writers, actively introducing ideas from Europe into China. After returning to China in 1934, apart from being a productive artist, Lü Sibai was professor and head of art departments at various tertiary institutions until his death in 1973. From the early 1950s Wang Linyi became professor of sculpture at China's Central Academy of Art in Beijing, where his career more or less took root. He was part of the team that created the "May Fourth Movement" relief on the People's Hero Monument at Tiananmen Square.

Chen Shiwen went to study art in Paris initially and was struggling financially for a while. By chance he was introduced to Cai Yuanpei, who wrote a letter of recommendation for him to be accepted by IFCL and receive a government scholarship. A prolific painter and sculptor, he later became head of the art history department at Chinese University of Hong Kong. His publications include a number of monographs on Chinese and European art history and ideas, and numerous catalogues of his art works.

\section{The Poet/Writer - Painters}

A number of art students at Lyon were better known for their literary achievements, such as Sun Fuxi 棌福熙 (1898-1962), Su Mei 蘇梅 (aka Su Xuelin 蘇雪林) and Huang Ye 黃葉 (1895- ?) (spelt as Vhan Ye or Whan Ye in ENBAL records). These artist-writers were themselves embodiments of one particular aspect of Chinese traditional elite culture, namely, the intimate relationship between writing and painting, and between the poet/ writer and the artist. Poetry and painting used to share the same media - brush, ink and paper. Paintings were often inspired by poetry and attempts were made to convey poetic imagery. Writings or calligraphy, in addition to the seals of the artists and owners of the painting, are an integral part of the visual image. This tradition meant that artists could be poets, and vice versa, at the same time. ${ }^{19}$ It is hence not surprising that these established writers came to Lyon's art school for education in art.

Sun Fuxi was a well-established literary figure in the Republican period. His brother, Sun Fuyuan 孫伏園 was editor for the influential literary supplement of The Morning Post (晨 
報副刊) in Peking from late 1910s to the mid 1920s. The Morning Post's literary supplement was the place where the leading Chinese thinkers and literary figures, such as $\mathrm{Hu}$ Shi 胡 適, Chen Xiying 陳西檾, Zhou Zuoren 周作人 and Lu Xun 魯讯, published their opinion pages and literary works. The Suns were from Shaoxing in Zhejiang Province, which made them fellow countrymen of Cai Yuanpei, Lu Xun, Xu Shoushang 許壽裳 and others. Although as a cultural figure Sun Fuxi was never as influential as his brother or others in his circle of friends, he did write and publish a great deal, primarily in the genre of xiaopinwen, prose essays of relatively short length.

In 1921, at the age of 23, Sun Fuxi enrolled to study painting at ENBAL. He was there for four years. He cherished his experience at Lyon and recalled his life and study in Lyon in many of his subsequent writings. He also continued his friendship with fellow French students in Lyon and wrote about how they continued to correspond and exchange Christmas presents through the post. Prior to studying Western painting at Lyon, Sun was trained in traditional Chinese ink-brush painting and his sense of aesthetics retained traces of that training, which is evident in many of the photographs he published later in various magazines. Some of his oil landscapes were also printed in various magazines but it is hard to judge the quality of his works due to the poor quality of the reproduction.

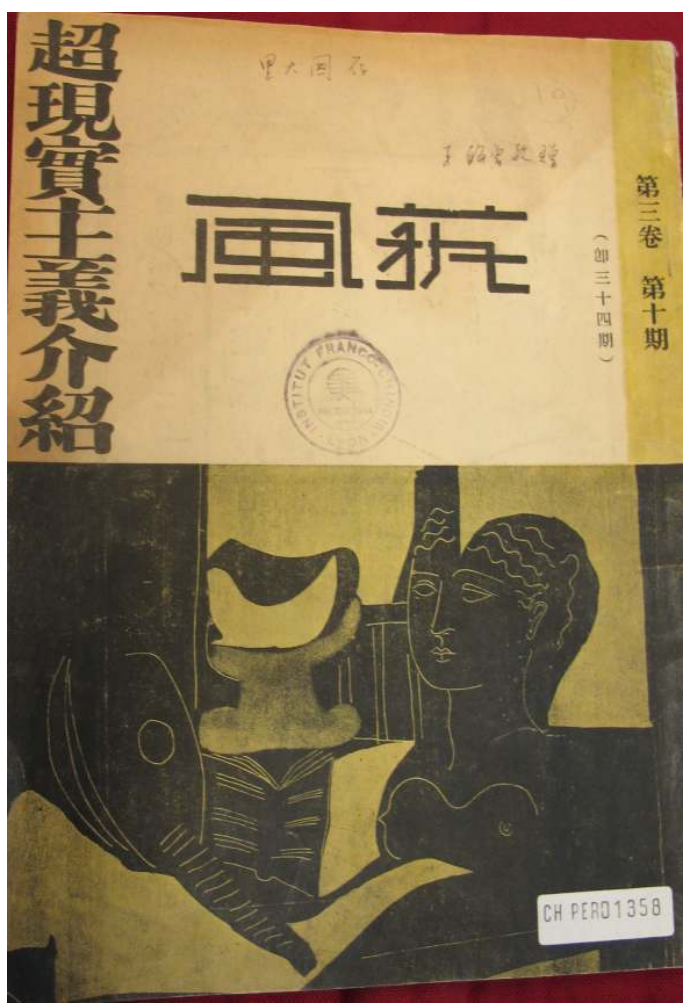

Cover of Yifeng 藝風 (Art Styles) for vol. 3, no. 10. This issue features surrealism.

A most significant contribution by Sun Fuxi to modern Chinese art was his founding of an art magazine Yifeng 藝風 (Art Styles) and the founding of the organisation Zhonghua duli meishu xiehui 中華獨立美術協會 (Independent Fine Art Association of China). He was the editor of the magazine, through which he organised art exhibitions and launched debates on art styles. The magazine also made serious attempts to introduce established and emerging Chinese artists. The few copies held at Lyon Municipal Library at La Part Dieu show that a number of Chinese artists were featured, including Zhao Sou, Xu Beihong, Lü Sibai, and Sun Fuxi himself. The magazine also featured special art 
exhibitions organised by the Independent Fine Art Association of China, and trends and practices in contemporary European art were extensively discussed. Sun Fuxi contributed a great deal to the writing. A Chinese book collector by the name of Xie Qizhang has collected a few issues of Yifeng and, in his opinion, it was one of the best art magazines of the time in 1930s China. ${ }^{20}$ Sun Fuxi's training at Lyon provided him with the knowledge and skills to edit an art journal that promoted the modernisation of art in China. After the PRC was established, he became an editor for People's Education Publishing House ( Renmin jiaoyu chubanshe) and held the position until 1957. He died in $1962 .{ }^{21}$ The Chinese search engine Baidu lists a number of entries on Sun Fuxi, where some of his paintings in Chinese ink and brush can be found. ${ }^{22}$ From information available in the public domain in China, it seems likely that Sun Fuxi became a rightist in 1957 and that political persecution subsequently led to his early death in 1962 at the age of 54 .

ENBAL records show Huang Ye enrolled in the school from 1925 to 1928. He studied decorative art, and in the school year of 1926-7 he was awarded first prize in mosaic design and a scholarship. My research to date has not uncovered any artworks by him but he served on the editorial board of Story World (Xiaoshuo shijie, English title as printed on the cover), a popular literary journal at the time. Clearly Huang was a prominent member for the journal, in which a photo of him and his wife was found. In each issue there were plates of paintings, sculptures or photography by Chinese or foreign artists. Huang and his involvement with writing and publishing on art are another example of how art education in Lyon contributed to the overall aim of modernisation of art in China.

Su Xuelin was registered as Su Mei in the records of IFCL. She is known to the Chinese public as a short story writer active in the 1920s and the 1930s after the May Fourth Cultural Movement. She has often been regarded by critics as one of the brilliant young women writers of the time, among other well-known names such as Bing Xin, Ling Shuhua and Ding Ling. Like these other women, her short stories are still in print today and much appreciated. Her iconoclastic criticism of Lu Xun, the foremost modern Chinese writer and intellectual, makes her controversial. ${ }^{23}$

Su Xuelin began studying in France during high school and matriculated in the French high school system. She entered IFCL when it was established in 1921 and was admitted as a student of painting at ENBAL in the same year. She had to abandon her studies two years later due to family matters, and it seems that she stopped painting completely after returning to China. A polemic with Lu Xun stopped her writing creatively and, as a result, she devoted her time to studying Chinese literary classics, such as works by Qu Yuan. She left for Taiwan in the 1940s and became professor of literature at National Cheng Kung University, where there is a research centre devoted to research on her. In 2014 a conference to honour her academic and artistic achievements was held at Cheng Kung University. ${ }^{24}$

Interestingly, Su Xuelin's experience in Lyon is hardly known to the general public or even by literary critics commenting on her work, except that at the Cheng Kung Conference in 2014, Zhang Xiaojun presented a paper on Su Xuelin's study in Lyon. Just as the cases of her fellow women writers/artists at the time, such as Ding Ling and Ling Shuhua, Su Xuelin's artistic engagement has remained in public oblivion. This group of women tended to come from families of the cultural elite and they belonged to what the Chinese would call cainü, the talented women, who were highly symbolic of the disappearing tradition of writing and painting among the cultural elite. 

Gao Xingjian, Jia Pingawa and Mu Xin, but they are by far a minority among writer, poets and artists. Even fewer are the artists who write both prose and poetry. The effort spent on art by people like Sun Fuxi and Su Xuelin seems not be repeated in our present times.

\section{Lyon's Connection with China's Quest for Modernity}

The cases of Chinese art students in Lyon demonstrate the process in which changes in both the concept and the practice of art in China as influenced by the Europeans occurred. In particular, they provide detailed illustrations of how the ideal of modernising China's art was put into practice with passion and perseverance by these individuals. These art students were at the grass-root level of China's engagement with European artistic traditions and their experiences of studying and practising Western art were an integral part of the process in China's adoption of Western concepts and practices for national modernisation.

Equally significant was the role of the city of Lyon and its fine arts school in the process. As a city, Lyon welcomed the Chinese students and provided them with all kinds of support, not least accommodation at the Fort of St. Irénée on the hills just outside Lyon's main transport hub of Perrache. Memoirs by the students, such as those of Sun Fuxi, are filled with fond memories of Lyon, showing not only the professional training the students received but also the long-lasting cultural influence of the people and local life of Lyon. The professionalism of Lyon's fine arts school is highly impressive. The Chinese students were taught in classes with local students and their achievements were equally valued and awarded.

Another tangible and enduring impact of Lyon's connection with China is the professionalisation of China's art education. After they returned to China, many of the Chinese students held important academic positions, such as Chen Shiwen, Lü Sibai, Jingyuan and Wang Linyi. Their posts entailed systematic institutionalisation of the European concepts and practices of art and laid the foundation for future development. Their teaching and practice back in China effectively translocated the French model of art education to China. To increase their influence and continue the momentum of art modernisation, they also formed professional associations and organised art exhibitions, such as those organized by Sun Fuxi and participated by his fellow students at ENBAL. Whether they were in teaching positions or not, they certainly carried out what Cai Yuanpei was promoting - the replacement of religion with aesthetic education.

Again the pivotal role of Cai Yuanpei should be reiterated. A leading intellectual at China's historical juncture of drastic political and social changes, Cai Yuanpei was both the proponent of aesthetic education of the general population and the political leader capable of implementing policies and ideas. Having spent eight years in Germany and travelled extensively in Europe, he was very keen for China to adopt ideas from European cultures and, in particular, the concepts and practices of art in Europe. He conceived the national art exhibitions at the very beginning of the Republic of China when he was appointed its Minister of Education. He was instrumental in facilitating students going overseas to study art and in institutionalising the measures for China's art education and also for the promotion of Chinese art overseas. Among many of Cai Yuanpei's successful

Transtext(e)s Transcultures 跨文本跨文化, 9 | 2014 
initiated were the establishment of IFCL, the Chinese art exhibition in Paris in 1933 and the opening of many fine art schools in China's major cities.

Dissemination of knowledge about art in the public domain was also consciously pursued by a number of the students after their Lyon experiences. Apart from reminiscing about their study at Lyon's art school, they also took it upon themselves as a duty to introduce Western art to the general public and fellow art professionals. They published art magazines and wrote articles, presenting significant world art historical figures and events as well as contemporary artistic trends and debates taking place outside of china. The large number and variety of publications received by IFCL from students show their enthusiasm and commitment. These publications cover a large range of topics on fine arts and they demonstrate not only the open-mindedness of those students towards styles and fashions in art but also the scope of their knowledge and aspirations for China's art modernisation.

To sum up, both Lyon and Chinese art students at ENBAL are important sites of cultural intersection in modern Chinese art history. The significance of Paris in China's art modernisation notwithstanding, it is important that Lyon's historical relevance to China be recorded and restored. This essay touches only the tip of the mountain of rich materials in Lyon concerning the effort of China's modernisation of art. Experiences of Chinese art students at ENBAL are extremely valuable as they demonstrate how the ideal for a modernised Chinese art was modelled largely on French art schools, and how the Chinese implemented their newly acquired knowledge and skills through institutional measures and individual efforts.

\section{BIBLIOGRAPHY}

Clark, John, Modernities of Chinese Art. Leiden: Brill, 2010.

Clark, John, "Trajectories of the National: Xu Beihong and Arthur Kampf in Inter-Asian

Comparison". Draft paper to be published.

Efland, Arthur, A History of Art Education: Intellectual and Social Currents in Teaching the Visual Arts. New York: Teachers College Press, 1990.

Von Kowallis, J.E., “The Enigma of Su Xuelin and Lu Xun”, Literature \& Philosophy, vol. 16, June 2010, p. 493-527.

Landi, Diana, Chang Shuhong, peintre chinois, 1904-1994: De Paris à Dunhuang. Paris: Imprimerie Zimmermann, 2011.

Lefebvre, Éric, ed. Artistes chinois à Paris. Paris: Musée Cernuschi, 2011.

Lü Peng 呂鵬, ed. Zhongguo yishu biannianshi 1900-2010 中國藝術編年史1900-2010 [A history of Chinese art year by year from 1900 to 2010]. Beijing: Zhongguo qingnian chubanshe, 2012.

Nelly, Gabriel, Histoires de l'École nationale des beaux-arts de Lyon. Lyon: Beaux Fixe, 2007. 
Qian, Zhongshu, Patchwork: Seven Essays on Art and Literature,trans. Duncan Campbell. Leiden: Brill, 2014.

Tang, Xiaobing, Origins of the Chinese Avant-garde: The Modern Woodcut Movement. Berkeley: University of California Press, 2008.

Villard, Florent, "Lieu d'énonciation, différence culturelle et conscience nationale: La Chine comme objet d'étude dans les thèses des étudiants de l'Institut franco-chinois de Lyon (1921-1946)", in Actes du Symposium international 2010: Langue, littérature et culture franco-chinoises du $21^{\text {ème }}$ siècle. Taipei: Département de Français, Université Tamkang, 2010, pp. 29-51.

Wang, Nora, Emigration et politique: Les étudiants-ouvriers chinois en France 1919-1925. Paris: Les Indes, 2002.

Wang, Yiyan, "Modernism and Its Discontent in Shanghai: The Dubious Agency of the SemiColonized in 1929" in Twentieth-Century Colonialism and China: Localities, the Everyday and the World, eds. Bryna Goodman and David S.G. Goodman, 2012, pp. 167-179.

Xiong, Qingyun 熊卿雲, “Faguo jiaoyu gaikuang [A brief introduction to the French education system], Chinese Educational Review, v. 15, no. 4, April 1923, pp. 23-25.

Yann, Philippe, “L'Institut franco-chinois: Un exemple réussi de collaboration en éducation?", PhD thesis, Université Lumière II, 2011.

\section{NOTES}

1. Research for this paper was conducted when I was Research Fellow at Collegium de Lyon from November 2013 to February 2014. I am grateful for support from Le Collegium de Lyon and from the University Research Fund at Victoria University of Wellington. I thank the efficient and professional help I received from the staff members at Lyon Municipal Archives at Perrache and Lyon Municipal Library at La Part Dieu, especially the assistance of Mr Marc Gilbert and Mr Olivier Bialais in charge of the Chinese collection.

2. For further information on China's first national art exhibition, see Yiyan Wang, "Modernism and Its Discontent in Shanghai: the Dubious Agency of the Semi-Colonized in 1929" in TwentiethCentury Colonialism and China: Localities, the Everyday and the World, Bryna Goodman and David S. G. Goodman, eds. 2012, pp. 167-179; Xiaobing Tang, Origins of the Chinese Avant-garde: The Modern Woodcut Movement. Berkeley: University of California Press, 2008.

3. See Lü Peng呂鵬, ed. Zhongguo yishu biannianshi 1900-2010 中國㙯術編年史 1900-2010 [A history of Chinese art year by year from 1900 to 2010]. Beijing: Zhongguo qingnian chubanshe, 2012, pp. 164-166

4. See, for instance, Éric Lefebvre, ed. Artistes chinois à Paris. Paris: Musée Cernuschi, 2011.

5. For a history of ENBAL, see Gabriel Nelly, Histoires de l'École nationale des beaux-arts de Lyon. Lyon: Beaux Fixe, 2007.

6. Arthur Efland, A History of Art Education: Intellectual and Social Currents in Teaching the Visual Arts. New York: Teachers College Press, 1990, pp. 54-55.

7. Xiong Qingyun 熊卿雲, “Faguo jiaoyu gaikuang 法國教育概況” [A brief introduction to the French education system], Chinese Educational Review, v. 15, no. 4, April 1923, pp. 23-25.

8. There have been a number of studies on IFCL. The PhD thesis entitled "L'Institut francochinois: Un exemple réussi de collaboration en éducation?" by Philippe Yann from Université Lumière II in 2011 is particularly informative about the origin, development, scale and undertakings of the Institute. My brief summary above is primarily based on this thesis. See also Florent Villard's article, "Lieu d'énonciation, différence culturelle et conscience nationale: La 
Chine comme objet d'étude dans les thèses des étudiants de l'Institut franco-chinois de Lyon (1921-1946)" in Actes du Symposium International 2010: Langue, littérature et culture francochinoises du $21^{\text {ème }}$ siècle. Taipei: Département de Français, Université Tamkang, Nov. 2010, pp. 29-51. I have also benefited from correspondence with Dr Hongling Liang, who assisted Lyon Municipality in organising an exhibition on IFCL in 2008. Moreover, information from and discussions with Professors Florent Villard and Gregory Lee of the University of Lyon III have also helped a great deal. In Xiong Qingyun's report on the French education system, he makes a brief but rather disparaging comment on IFCL, stating that IFCL functioned like a preparation college (Xiong Qingyun, "A brief introduction to the French Education System", p. 25).

9. On the internet, there are claims that she was 41 when she went to Lyon to study. In the ENBAL registration record, she was recorded as having been born in 1896. According to the IFCL registration form, her birth year was 1893. I take the IFCL record to be closer to the truth, since the administration there are likely to have had better communication with the Chinese students.

10. In Wang Jingyuan's file there is a letter written by the Secretary of ENBAL addressed to the President of IFCL to inform him of Wang Jingyuan's winning the scholarship competition.

11. See the file of Wang Jingyuan at Lyon Municipal Library, \#138, documents 26-28.

12. I have not yet been able to conduct further research on Wang Jingyuan in China before completing this essay.

13. Éric Lefebvre's edited volume, Artistes chinois à Paris (Paris: Musée Cernuschi, 2011) has information on the exhibition and on Pan Yuliang. Samples of her works are on pages 172-193. John Clark's draft paper, "Trajectories of the National: Xu Beihong and Arthur Kampf in InterAsian Comparison" offers detailed analysis of Pan Yuliang's works and her artistic achievements. John Clark's book, Modernities of Chinese Art is also informative (Leiden: Brill, 2010).

14. See file no. 270 in the Chinese collection at Lyon Municipal Library.

15. Diana Landi, Chang Shuhong, peintre chinois, 1904-1994: De Paris à Dunhuang, Paris: Imprimerie Zimmermann, 2011, p. 24.

16. Francesca Dal Lago, "Malade fiévreuse: Chang Shuhong" in Éric Lefebvre, ed., Artistes chinois à Paris, pp. 84-5.

17. The two books are: Diana Landi, Chang Shuhong, peintre chinois, 1904-1994: De Paris à Dunhuang, Paris: Imprimerie Zimmermann, 2011 and Éric Lefebvre, Artistes chinois à Paris, Paris: Musée Cernuschi, 2011.

18. Diana Landi, Chang Shuhong, peintre chinois, 1904-1994: De Paris à Dunhuang, Paris: Imprimerie Zimmermann, 2011, p. 34.

19. See, for instance, Qian Zhongshu's essay on the intimate connection between poetry and painting in China's cultural traditions. Qian Zhongshu, "Chinese Poetry and Chinese Painting" in Qian Zhongshu, Patchwork: Seven Essays on Art and Literature. Duncan Campbell, Leiden: Brill, 2014, pp. 29-78.

20. See the website: http://epaper.jwb.com.cn/jwb/html/2014-03/29/content_1088874.htm accessed 15 December 2014.

21. According to unpublished research notes by Dr Liang Hongling, Sun Fuxi was editor for People's Education House from 1951 to 1957. He died of ill health in 1962 at the age of 54.

22. See http://baike.baidu.com/view/213428.htm accessed 15 December 2014.

23. For Su Xuelin and Lu Xun, see Jon von Kowallis, "The Enigma of Su Xuelin and Lu Xun", Literature \& Philosophy, vol. 16, June 2010, pp. 493 - 527.

24. See http://suxuelin.liberal.ncku.edu.tw access on 8 Janurary 2015. 


\section{ABSTRACTS}

The twentieth century saw China undergo significant political, social and cultural transformations. Modernisation of art was an integral part of China's national modernisation project. L'École nationale de beaux-arts de Lyon provided training to at least 58 students from China from 1920 to 1942. Lyon's connection with modern Chinese art history, however, has not been sufficiently examined. As part of a larger project that examines the process of China's art modernisation at the beginning of the twentieth century, this paper explores the significance of Lyon as a location of cultural intersection through selected cases of Chinese art students in Lyon. By documenting and analysing the process through which those individual students undertook the challenges of acquiring European concepts and practice of art, this paper demonstrates how the ideal for a modernised Chinese art was modelled largely on French art schools, and how the Chinese implemented their newly acquired knowledge and skills through institutional measures and individual efforts.

\section{AUTHOR}

\section{WANG YIYAN}

Yiyan Wang is Professor of Chinese and Chinese Programme Director in the School of Languages and Cultures at Victoria University of Wellington in New Zealand. She currently works on modern Chinese intellectual history and Chinese diaspora studies. 